\title{
未破裂脳底動脈先端部動脈瘤の自然経過と外科治療
}

\author{
竹 本 光一郎*1 井上亭*1 卯 田 健*2
}

\section{Conservative Treatment \& Surgical Treatment of Unruptured Basilar Tip Aneurysms}

by

Koichiro Takemoto, M.D. ${ }^{* 1}$, Tooru Inoue, M.D. ${ }^{* 1}$, and Ken Uda, M.D. ${ }^{* 2}$

from

${ }^{* 1}$ Department of Neurosurgery, Fukuoka University School of Medicine

*2Department of Neurosurgery, National Hospital Organization, Kyushu Medical Center

We retrospectively analyzed the ten year results of our experience in the treatment of 39 unruptured basilar artery tip aneurysms by either conservative treatment or surgical treatment (direct surgery or coil embolization).

Direct surgery was performed in seven cases. Successful clipping was performed in five cases, and wrapping in two cases. Endovascular treatment was performed in ten cases. There were eight cases of complete occlusion, one case of neck remnant, one case of dome filling. Therapeutic result of surgical treatment were $5.9 \%$ permanent morbidity and no mortality. Long-term follow-up revealed only one aneurysmal rupture in the surgical group. Conservative treatment in 22cases, aneurysmal rupture was found in six cases (annual rupture rate was 9.2\%). Our management of the unruptured basilar artery tip aneurysms provide satisfactory therapeutic result in the surgical group. It is important in selecting the best method of treatment for the unruptured basilar artery tip aneurysms: direct surgery, endovascular treatment, conservative treatment.

(Received October 17, 2008 ; accepted February 9, 2009)

Key words : unruptured basilar artery tip aneurysm, surgical treatment, conservative treatment Jpn J Neurosurg (Tokyo) $18: 681-686,2009$

\section{はじめに}

近年 MRI を中心とする画像診断の進歩や脳ドックの 普及から未破裂動脈瘤が発見される頻度が増加してお り,これに伴いわれわれが動脈瘤破裂の予防的治療に携 わる機会も増加してきた。しかしながら，その治療方針 決定には各動脈瘤の自然歴と治療リスクの十分な検討が 必要であり，さらには患者本人およびその家族に十分な 説明を行い，それぞれの意向により最終的な治療方針を 決定する必要がある。このうち脳底動脈先端部動脈瘤は, UCAS Japan の調查報告5)によれば，その他の動脈瘤と比 較して破裂率が高く, よりいっそうの配慮が必要と思わ
れる.未破裂動脈瘤の自然歴および治療成績については, 種々の報告により, 破裂率, 合併症頻度に差があり, 必 ずしもそれらのデータが自施設に当てはまるものではな いと考元られる。.今回わ机われは，自施設における未破 裂脳底動脈先端部動脈瘤の外科治療群と経過観察群の治 療成績と転帰を調査し報告する。

\section{対 象}

症例は, 1996〜2006 年までに国立病院機構九州医療セ ンター脳神経外科で外科治療あるいは経過観察を行った 未破裂脸底動脈先端部動脈溜の連続 39 例であり, 経過

\footnotetext{
*1福岡大学医学部脳神経外科 $/ \bar{T} 814-0180$ 福岡市城南区七隈 7-45-1〔連絡先：竹本光一郎〕

Address reprint requests to: Koichiro Takemoto, M.D., Department of Neurosurgery, Fukuoka University School of Medicine, 7-451 Nanakuma, Jounan-ku, Fukuoka-shi, Fukuoka 814-0180, Japan

*2国立病院機構九州医療センター脳神経外科
} 
Table 1 The size of aneurysms

\begin{tabular}{ccccc}
\hline Size & $3 \sim 4 \mathrm{~mm}$ & $5 \sim 6 \mathrm{~mm}$ & $7 \sim 9 \mathrm{~mm}$ & $10 \sim 24 \mathrm{~mm}$ \\
\hline Direct surgery $(n=7)$ & 0 & 2 & 2 & 3 \\
Endovascular $(n=10)$ & 1 & 7 & 2 & 0 \\
Conservative $(n=22)$ & 4 & 4 & 6 & 8 \\
\hline
\end{tabular}

Table 2 Therapeutic result of surgical group

\begin{tabular}{ccccccccc}
\hline \multirow{2}{*}{ GOS } & \multicolumn{2}{c}{ Preoperative state } & & \multicolumn{2}{c}{ Postoperative state } & & \multicolumn{2}{c}{ Final follow-up } \\
\cline { 2 - 3 } & Direct surgery & Endovascular & & Direct surgery & Endovascular & & Direct surgery & Endovascular \\
\hline GR & 5 & 10 & & 6 & 10 & 6 & 0 & 0 \\
MD & 2 & 0 & & $1 * 1$ & 0 & 0 & 0 \\
SD & 0 & 0 & & 0 & 0 & 0 & $1^{* 2}$ & 0 \\
D & 0 & 0 & 0 & 0 & 0 \\
\hline
\end{tabular}

GOS; Glasgow Outcome Scale, GR; good recovery, MD; moderate disability, SD; severe disability, D; death, ${ }^{* 1}$ Oculomotor palsy, ${ }^{* 2}$ Ruptured after the wrapping

観察群 22 例, 外科治療群 17 例（直達手術 7 例, コイル 塞栓術 10 例）を対象とした．検討項目は，治療法別で の(1)患者年齢, (2)脳動脈瘤サイズ, (3)治療成績および合 併症，退院時およびその後の転㷌，(4)経過観察群におけ る選択理由，破裂例抢よび年間破裂率，(5)破裂例の関連 因子である。

\section{治療方針}

1996〜2000 年までの症例については, 通常高位であれ ば根治性の高い直達手術を第一選択としたが，それ以降 は手術難易度や侵襲性の観点からコイル塞栓術を第一選 択とした. 最終的な決定は, 脳動脈瘤の特徴（サイズ, 形状）のみならず，患者側の因子 (年齢, 全身状態, ク モ膜下出血の家族歴，人生観や患者背景など）を考慮し 決定した。直達手術は全例, 通常の transsylvian approach で行われ，コイル塞栓術は Guglielmi detachable coil （GDC）を用いて両治療ともに単一術者によって行われ た。治療達成度については, 直達手術群でクリッピング もしくはラッピング, コイル塞栓群で complete occlusion (CO), neck remnant (NR), dome filling (DF) に分類 し, 退院時およびその後の転帰を Glasgow Outcome Scale （GOS）で評価した。

\section{結 果}

\section{1 患者年齢}

治療法別の年齢は, 経過観察群で平均 67.7 歳 $(50 \sim 79$
歳), 直達手術群で 64.1 歳（55～74 歳）, コイル塞栓群 で 58.5 歳（24〜75 歳）であり, 全体の平均は 64.5 歳で あった。

\section{2 動脈瘤サイズ}

経過観察群では, 3〜 $4 \mathrm{~mm}$ が 4 例, 5 6 $\mathrm{mm}$ が 4 例, 7 9 $\mathrm{mm}$ が 6 例, $10 \sim 24 \mathrm{~mm}$ が 8 例であり, 直達手術 群では 3〜 $4 \mathrm{~mm}$ はなく, 5 6 $\mathrm{mm}$ が 2 例, $7 \sim 9 \mathrm{~mm}$ が 2 例, $10 \sim 24 \mathrm{~mm}$ が 3 例と, 両群ともに $25 \mathrm{~mm}$ 以上の 巨大動脈瘤はないものの比較的大型の動脈瘤が多い結果 であった。コイル塞栓群では, $3 \sim 4 \mathrm{~mm}$ が 1 例, $5 \sim 6 \mathrm{~mm}$ が 7 例, 7〜9 $\mathrm{mm}$ は 2 例, 10〜24 $\mathrm{mm}$ はなく, 経過観 察群, 直達手術群と比較して小型の動脈瘤が多く, 同じ く $25 \mathrm{~mm}$ 以上の動脈瘤はなかった（Table 1).

\section{3 治療成績および合併症}

\section{1. 直達手術群}

7 例中 5 例でクリッピングが施行でき, 残り 2 例はそ れぞれ neck の高度石灰化, 血豆状動脈瘤の所見からラッ ピングを施行した。退院時の GOS は, good recovery (GR) が 6 例, moderate disability（MD）が 1 例であった. 3 例に動眼神経麻痺を認めたが, 術後新たに動眼神経麻痺 が出現したのは 1 例のみで, 残り 2 例は術前より同様の 症状が認められた。 また 3 例中 2 例は最終的にはほぼ完 全寛解している。しかしながら改善がなかった残りの 1 例はラッピングを施行した症例で， 2 年後にクモ膜下出 血をきたし死亡した。最終の転帰は，GR が 6 例, death （D）が 1 例であった（Table 2). 
Table 3 Result of conservative treatment

\begin{tabular}{ccccc}
\hline Size & $3 \sim 4 \mathrm{~mm}$ & $5 \sim 6 \mathrm{~mm}$ & $7 \sim 9 \mathrm{~mm}$ & $10 \sim 24 \mathrm{~mm}$ \\
\hline No change & 4 & 4 & 4 & 3 \\
Increase & 0 & 0 & 2 & 0 \\
Rupture & 0 & 0 & 1 & 5 \\
\hline
\end{tabular}

Table 4 Aneurysmal rupture cases of conservative treatment

\begin{tabular}{ccccccc}
\hline Case & Age/sex & Size of An & Follow -up & H \& K grade & Treatment & GOS \\
\hline 1 & $50 \mathrm{~F}$ & 16 & 8 years & 3 & endovascular & GR \\
2 & $65 \mathrm{~F}$ & 8 & 5 years & 3 & endovascular & GR \\
3 & $64 \mathrm{M}$ & 10 & 6 months & 4 & endovascular & GR \\
4 & $69 \mathrm{~F}$ & 14 & 1 months & 3 & endovascular & MD \\
5 & $65 \mathrm{~F}$ & 20 & 2 years & 5 & - & D \\
6 & $79 \mathrm{~F}$ & 22 & 6 months & 5 & - & D \\
\hline
\end{tabular}

$\mathrm{M}$; male, F; female, An; aneurysm, H \& K grade ; Hunt \& Kosnik grade, GOS ; Glasgow Outcome Scale, GR ; good recovery, $\mathrm{MD}$; moderate disability, $\mathrm{SD}$; severe disability, $\mathrm{D}$; death

Table 5 Multivariate analysis

\begin{tabular}{ccccc}
\hline Variable & S.E. & $p$ value & R & Hazard ratio $(95 \%$ C. I. $)$ \\
\hline Size & 0.078 & 0.0704 & 0.21 & $1.15(0.99 \sim 1.34)$ \\
Multi & 1.049 & 0.0412 & 0.28 & $8.51(1.09 \sim 66.44)$ \\
\hline
\end{tabular}

S. E. ; standard error of mean, R ; contribution rate, C. I. ; confidence interval

\section{2. コイル塞栓群}

治療達成度としては, $\mathrm{CO}$ が 8 例, NR が 1 例, DF が 1 例であり, 退院時の GOS は全例 GR であった。退院後 は 3 力月目に MRI, 6 力月目に血管撮影を施行し, 以後 1 年ごとに MRI で経過観察したが (平均観察期間は 23.2 カ月), 所見の増悪を認めた症例および破裂をきたした症 例はなく，最終の転帰も同様に全例 GR と良好であった (Table 2).

\section{4 経過観察群における選択理由, 破裂例および 年間破裂率}

まず経過観察の選択理由は, 小サイズが 2 例, 高龃が 1 例，全身的問題が 1 例，治療困難が 7 例（このうち 2 例は実際に血管内治療が試みられたが困難であった), 治 療についての十分な説明を行ったうえで最終的に患者希 望により経過観察となった症例が 11 例と最も多かっ た. 臨床的経過観察は全 22 例で行われ（平均観察期間 35.5 力月), 画像経過観察は 21 例で施行できた（平均観 察期間 27.5 力月)。このうち破裂をきたしたのは 6 例 (27.3\%)，增大を認めた症例は 2 例 $(9.1 \%)$ ，変化なし が 15 例 $(68.2 \%)$ であり, 高率に破裂を経験した（Table
3)。年間破裂率は $9.2 \%$ ，年間累積破裂率は $20 \%$ であっ た (Kaplan-Meier 法)。破裂をきたした 6 例中 4 例はコ イル塞栓術を施行し，残り 2 例は発症時 Hunt \& Kosnik grade 5 であり，死亡の転帰となった（Table 4). 最終的 な転帰としては，GR が 18 例，MD が 1 例, severe disability（SD）が 1 例, D が 2 例と, 外科治療群と比較し て明らかに不良であった。

\section{5 破裂に関連する因子}

Stepwise Cox proportional hazards model を用いた多変 量解析を行った。背景因子としては，年齢，性別，動脈 瘤サイズ，多発例，クモ膜下出血の家族歴について検討 し，動脈瘤サイズ $(p=0.07)$, 多発例 $(p=0.04)$ で破裂 への影響が示唆された（Table 5)。なお，クモ膜下出血 の家族歴は経過観察群では 1 例のみにみられ, 直達手術 群で 2 例，コイル塞栓群では認められなかった。

\section{代表症例提示}

\section{【症例 2】}

患 者: 65 歳, 女性 


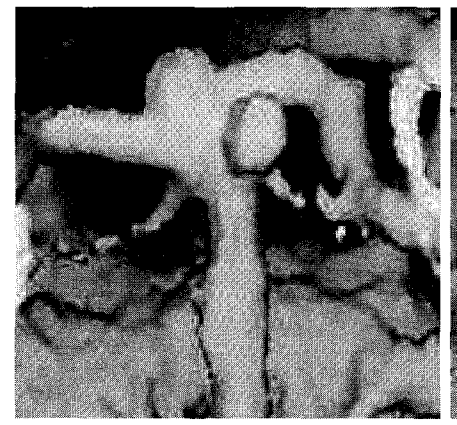

1996

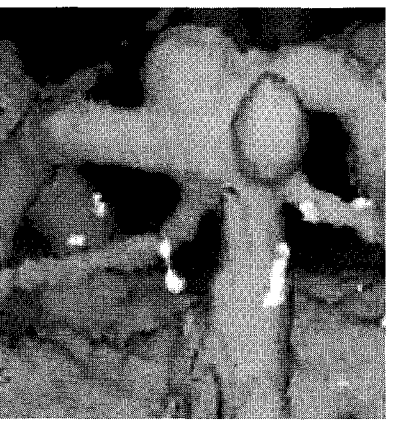

2 years later

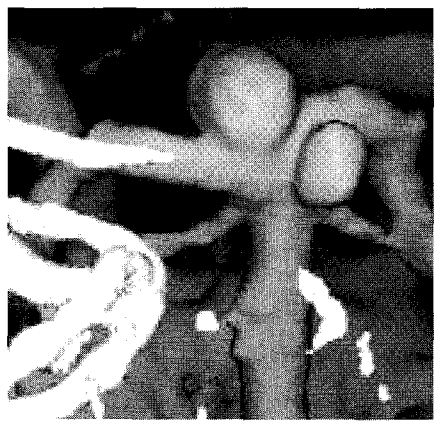

4 years later

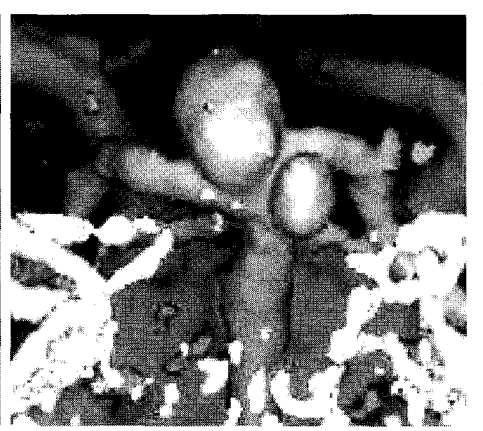

6 years later (rupture)

Fig. 1 Case 1: 65 years old female

3D-CTA showed the BA tip and the It. BA-SCA aneurysm. The BA tip aneurysm gradually increased while followup. Finally, she presented with a SAH at six years after diagnosis.
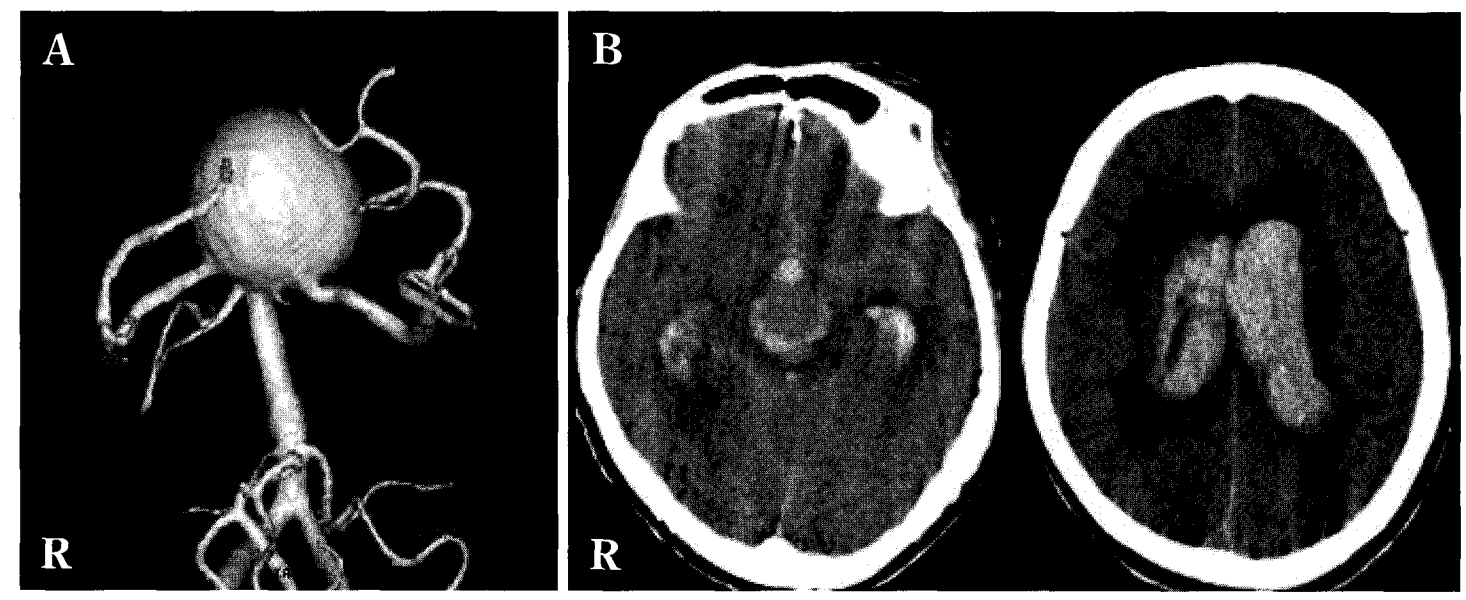

Fig. 2 Case $2: 79$ years old female

A : 3D-angiography showed the BA tip large aneurysm $(22 \mathrm{~mm})$.

B : CT showed a SAH at six month after diagnosis.

1996 年, 未破裂左中大脳動脈瘤にてクリッピングを施 行されており，この時，脳底動脈先端部および左脳底動 脈上小脳動脈分岐部動脈溜を指摘されていたが，溜の形 状より治療リスクが高いと判断し，外来で画像検査を行 い, 経過観察の方針となった. 2000 年に computed tomography angiography (CTA) にて脳底動脈先端部動脈瘤の 增大を認め (Fig. 1)，治療を勧めたが決心がつかず, 2002 年にクモ膜下出血で来院された。この時，脳底動脈先端 部動脈溜はさらに増大しており，コイル塞栓術を施行し た。術後経過は良好で神経症状なく元気で退院された。

\section{【症例 6】}

患 者: 79 歳, 女性

2005 年 6 月, 間欠的頭痛, 痴呆症状から近医を受診し MRI 上，第三脳室腫瘍を疑われて入院となった．血管撮 影にて $22 \mathrm{~mm}$ 大の大型動脈瘤を認めたが (Fig. 2), neck より両側後大脳動脈が分岐しており，高齢であることか
らも外科治療のリスクは高く, 家族との協議のうえ, 経 過観察の方針となった。 2006 年 1 月, クモ膜下出血にて 来院. 翌日に死亡退院となった。

\section{考 察}

International study ${ }^{6)}$ や UCAS Japan ${ }^{5)}$ にいても, 脳底 動脈先端部動脈瘤は他の部位の動脈瘤よりも高い破裂率 を呈することは周知の事実であるが，われわれの調査で は経過観察群 22 例において 6 例, $27.3 \%$ というきわめて 高率な破裂を経験し, 年間平均破裂率 $9.2 \%$, 年間累積 破裂率は $20 \%$ という結果であった。これは前述の大規模 試験と比較してかなり高い破裂率であった。一方で未破 裂動脈瘤の真の自然歴をみるためには, 多数の症例でか つ全例について手術することなく一定期間観察する必要 があり ${ }^{1)}$, 実際の臨床においてこれは大変困難なことで ある、本研究のように自施設での動脈瘤破裂率を検討し 
た報告は多いが2338)99，ほとんどの場合，症例数が少な いため個々の破裂率はあまり自然歴としての意味をもた ないと思われる．また外科治療群を含むためバイアスを 生じている。無作為試験ではないため, 本研究から治療 の妥当性を検討することは困難であるが，自施設での経 過観察群と外科治療群の予後比較という点からは意味の ある調査であると思われる。

外科治療群と経過観察群の比較においては，まずクモ 膜下出血の発症をどこまで防げるかということが重要で ある，本研究は無作為試験ではなく, 動脈瘤サイズにお いても外科治療群と経過観察群に差異を生じていること から純粋な比較にはならないが, 外科治療群の $5.9 \%$ （1/ 17 例), 経過観察群の $27.3 \%$ に破裂を経験し, 外科治療 群で明らかに低い結果となった。最終的な転帰について も，破裂例 1 例を除いて全例 GR であったことは満足い く結果である. 本研究における経過観察群の高い破裂率 は未破裂脳底動脈先端部動脈瘤の治療方針を考えるうえ で大変重要である。

・動脈瘤サイズと治療方針

本研究において動脈瘤破裂に関連した因子は，動脈瘤 サイズ $(p=0.07)$, 多発例 $(p=0.04)$ であり, $7 \mathrm{~mm}$ 以 下での破裂はなく, $13 \mathrm{~mm}$ 以上の 6 例中 4 例 $(66.7 \%)$ で破裂を経験しており，大型動脈瘤で治療ができると判 断した場合は積極的に治療を勧めるべきと思われる (Table 3).

大型脳動脈瘤で破裂萃が高くなることは周知である が, 治療による合併症率も当然高くなる。山田ら ${ }^{7)}$ は脳 底動脈先端部動脈溜 50 例の治療成績を検討している が，10 $\mathrm{mm}$ 以上 $25 \mathrm{~mm}$ 未満の 10 例においては, 開頭手 術群で $3 / 3$ 例, 血管内治療群 $5 / 7$ 例が GR といずれの治 療法でも安定した成績が得られているのに対し，25 $\mathrm{mm}$ 以上では 4 例中 3 例が poor outcome と非常に撖し い結果であった。これらの巨大脳動脈瘤に関してはいず れの方法を用いても治療成績は不良であり, 適応は慎重 にならざるをえないのが現状である。しかしこれらの難 治性脳動脈瘤に対する新たな展望もみられる。直達手術 では bypass surgery を加えることで動脈溜の盲端化を図 る試みが報告されており立，血管内治療においては最近， 本邦でも bioactive coil の使用が可能となり, healing proc- ess による塞栓効果の改善が予想される，未破裂脳底動 脈先端部動脈瘤は破裂しやすく積極的治療の対象であ り, これらの方法を加え，今後もさらなる治療成績向上 を目指す必要がある。

\section{まとめ}

当院での未破裂脳底動脈先端部動脈瘤 39 例の検討に おいて，外科治療群 17 例（直達手術，コイル塞栓術） では治療合併症，治療後の破裂率ともに $5.9 \%$ という結 果であった。経過観察群では $27.3 \%$ と高率に破裂を経験 し，特に大型脳動脈溜（13 $\mathrm{mm}$ 以上）では $66.7 \%$ 破裂 しており，積極的に治療を考慮する必要がある。

\section{文 献}

1) Juvela S, Porras M, Heiskanen $O$ : Natural history of unruptured intracranial aneurysms: A long-term follow-up study. J Neurosurg 79: 174-182, 1993.

2）松本勝美, 赤木功人, 安部倉信, 山本和己, 中島義和, 加藤天美, 甲村英二, 吉峰俊樹: 未破裂動脈溜手術例. 非手術例の経過よりみた治療上の問題点. 脳卒中の外科 29: 155-159, 2001.

3）長嶺義秀，清水宏明，富永悌二，江面正幸，高橋 明, 吉本高志：無症候性未破裂動脈瘤の治療方針。脳卒中の 外科 29:166-171, 2001 .

4) Takahashi JC, Murao K, Iihara K, Nonaka Y, Taki J, Nagata I, Miyamoto S: Successful "blind-alley" formation with bypass surgery for a partially thrombosed giant basilar artery tip aneurysm refractory to upper basilar artery obliteration: Case report. J Neurosurg 106:484-487, 2007.

5）UCAS Japan 事務局：日本未破裂脳動脈瘤悉皆調査 (UCAS Japan)：中間報告III. 脳外誌 13：163-169, 2004 .

6) Unruptured intracranial aneurysms -Risk of rupture and risks of surgical intervention. The interventional study of unruptured intracranial aneurysms investigators. $N$ Engl J Med 339: 1725-1733, 1998.

7）山田圭介, 宮本 享, 橋本信夫, 永田 泉, 菊池晴彦, 野崎和彦, 定藤章代, 佐藤徹, 滝 和郎: 未破裂脳底 動脈先端部動脈瘤の治療一 50 例の検討一. 脳卒中の外科 31: 183-186, 2003.

8) Yasui N, Suzuki A, Nishimura H, Suzuki K, Abe T: Longterm follow-up study of intracranial aneurysms. Neurosurg 40: 1155-1160, 1997.

9）渡邉陽祐, 沖 修一, 隅田昌之, 磯部尚幸, 加納由香利, 武田正明：無症候性未破裂脳動脈瘤の治療方針と治療成 績.脳卒中の外科 $33: 95-100,2005$. 
未破裂脳底動脈先端部動脈瘤の自然経過と外科治療

$$
\text { 竹本光一郎 井上 亨 卯田 健 }
$$

過去 10 年間の当院における未破裂脳底動脈先端部動脈瘤 39 症例（直達手術, コイル塞栓術, 経過 観察）の治療成績とその後の転帰について調査，検討し報告する．直達手術は 7 例に施行され，開頭 クリッピング 5 例, ラッピング 2 例であった. コイル塞栓術は 10 例に施行され， 8 例が complete occlusion, 1 例が neck remnant, 1 例が dome filling であった．直達手術群における永続性合併症は クリッピングを施行された 1 例で生じ (動眼神経麻䡇)，長期経過においてラッピング術を施行した 1 例に破裂を経験した．コイル塞栓群では治療合併症はなく，術後画像評価において所見の増悪や破 裂は認められなかった，外科治療群全体における治療合併症，治療後の破裂率ともに $5.9 \%$ という結 果であった，一方，経過観察群 22 例においては 6 例 $(27.3 \%)$ と高率に破裂を経験した（年間破裂 率 9.2\%)．未破裂脳底動脈先端部動脈瘤は破裂しやすく，積極的に治療を考慮する必要がある．

脳外誌 $18 ： 681-686,2009$ 